\title{
Using a quantitative model for participatory geo-foresight: ISIS-Fish and fishing governance in the Bay of Biscay
}

\author{
Provot Zoe ${ }^{1}$, Mahévas Stéphanie ${ }^{1,}{ }^{*}$, Tissière Laurie ${ }^{1,2}$, Michel C. ${ }^{3}$, Lehuta Sigrid ${ }^{1}$, Trouillet B. ${ }^{2}$
}

\author{
1 Ifremer, Unité Écologie et Modèles pour l'Halieutique (EMH), F-44311 Nantes 03, France \\ 2 Université de Nantes, CNRS, UMR LETG, Chemin de la Censive du Tertre, BP 81227, 44312 Nantes \\ Cedex 3, France \\ 3 Usages et Territoires, Toulouse, France \\ * Corresponding author : Stéphanie Mahévas, email address : stephanie.mahevas@ifremer.fr \\ zoe.provot@laposte.net ; laurie.tissiere@etu.univ-nantes.fr ; michelterritoires@free.fr ; \\ Sigrid.lehuta@ifremer.fr ; Brice.Trouillet@univ-nantes.fr
}

\begin{abstract}
:
This study investigated the use of a complex quantitative simulation model for participatory geo-foresight for the governance of the marine socio-ecosystem in the Bay of Biscay. The approach is simulation-based combining qualitative and quantitative expert-knowledge focusing on the demersal fishery in the Bay of Biscay. A three-stage approach was carried out : (i) translation by stakeholders of a narrative scenario drawn up during the geo-foresight into quantitative sub-scenarios that could be parameterized in ISISFish; (ii) simulation with ISIS-Fish and study of the consequences of the sub-scenarios on the dynamics of the fishery; and (iii) participants feedback on the relevance of the model, on the possibility to detail the narrative scenario further and on the general contribution of ISIS-Fish to geo-foresight. The study created discussions on input data, mechanisms and spatial features of the model and on some limits of simplistic translations of the scenario. The model and simulations highlighted the relevance of using a spatial model to explore sub-scenarios derived from geo-foresight. The flexibility of ISIS-Fish and the synergy between the quantitative modeling and scenario planning approaches allowed for demystification of complex models for fisheries management and illustrated their potential for decision-making for fisheries management.
\end{abstract}

Keywords : Geo-foresight, Participatory, Spatial, Complex quantitative, model, ISIS-Fish, Scenarios, Fishery dynamics, Bay of Biscay 
2 The diversification of offshore activities continues to increase (e.g. offshore wind farms, marine 3 aggregate extraction, aquaculture, etc) and maritime space is more than ever the subject of social, 4 economic and environmental conflicts (Mackinson and Wilson, 20I4; Thébaud et al, 20I4). The 5 diverse nature of the changes affecting this space is such that a sectorial approach is no longer 6 adequate and a system-wide approach is required for successfully sharing the space and its resources 7 within a multi-stakeholder framework (van Hoof et al 20I2). Several framework directives (e.g. 8 Directive 2014/89/EU establishing a framework for maritime spatial planning and Directive 9 2008/56/EC Marine Strategy Framework Directive) have provided the basis for the measures drawn Io up by the European Commission (EC) covering the good environmental status of marine waters and II the planning for the use of these waters.

I2 In general, the fisheries management measures adopted by the EC result from a (not very I3 transparent, Gascuel et al, 2008) compromise between economic, environmental and social I4 objectives. Each year, the EC consults the working groups of the International Council for the I5 Exploitation of the Sea (ICES) and the Scientific, Technical and Economic Committee for Fisheries I6 (STECF) to provide guidelines for its decisions on marine fishing management (Lequesne, 1999). I7 These bodies assess the status of the fishing stocks using indicators (e.g. biomass $B$, fishing mortality I8 $F$, fishing effort $E$, etc) on the one hand and, on the other, evaluate the management measures which I9 would maintain the good environmental status of fish stocks and fleet performances (e.g. total 20 allowable catch (TAC), marine protected areas, and, more recently, landing obligation) (Caddy and 2I Mahon, 1996). Scientific working groups make extensive use of quantitative models. By studying the 22 consequences of the management measures on marine population dynamics, fishing dynamics and 23 the economy (Lehuta et al., 20I3, Fulton et al., 20II), quantitative models are determinants for 24 decision-making processes (Lehuta et al 2016, Fulton et al., 2011). However, certain gaps in the 
25 knowledge of the dynamics studied (e.g. growth rate, recruitment, fishing effort transfer) constitute 26 an obstacle to sustainable management of the whole socio-ecosystem. To reduce potential bias in 27 stock estimates (Biais, 1993) and improve the evaluation of management measures and their 28 acceptation, it appears to be essential for fishermen, managers and scientists to share knowledge 29 (Tissière et al, 2018a, Linke et Bruckmeier, 20I5, Stephenson et al. 2016).

30 To encourage this, the EC calls on the participation of stakeholders in the decision-making process 3I (reform of the Common Fisheries Policy (CFP), 2002; setting up of Regional Advisory Councils 32 (RAC), 2004). So far, the lack of transparency in the decision process and the complexity of the 33 models were seen as impediments to the participatory processes (van Hoof 2015). However, methods 34 exist to introduce stakeholders to (complex) quantitative models, and make models a support to 35 share actor's expertise, discuss the design of management scenarios, and endorse the outputs of the 36 evaluations which form the basis of policy decisions.

37 Geo-foresight can be used to orchestrate a participatory approach managing the complexity of the 38 studied system, the spatial aspects of the system and the participation of stakeholders. It combines 39 "future studies" (i.e. making preparations for the short term and setting the foundations for the 40 future (De Jouvenel and Fish, 2004), geography and modeling (Gourmelon et al., 20I2; Houet and 4I Gourmelon, 20I4). It is a discipline in development with no fixed definition or formal methodology. 42 Geoforesight sets out to build a range of scenarios for a system by taking into account the three 43 keystones of sustainable development (i.e. ecology, social science and economics) (De Jouvenel and 44 Fish, 2004; Houet and Gourmelon, 2004; Godet, 200I; Mermet, 2005). Scenarios are defined here as 45 alternative dynamic stories telling about integrated and provocative alternative futures (Peterson et al 46 2003, Kahn and Wiener 1967). Geo-foresight includes and is structured around spatial aspects at all 47 stages in drawing up the scenarios (Gourmelon et al., 2012). By encouraging debate, this approach 
helps stakeholders to anticipate changes, in particular spatial long-term changes in their environment and activities (De Jouvenel and Fish, 2004; Godet, 200I).

50

SI

Such an approach has been carried out in the Bay of Biscay, where a group of stakeholders concerned with maritime fisheries governance were invited to discuss the future of this maritime space, particularly in terms of spatial changes and to create (narrative) scenarios of the future of the fishing industry. As part of this study, discussion workshops were held over two years. A complex quantitative model was used to illustrate with quantitative variables the qualitative scenarios formulated during these workshops with a focus on the demersal fisheries of the Bay of Biscay (see Tissière et al 2016, Tissière et al 20I8b for the details of this participatory foresight approach).

In this paper, we focus on one of the original aspects of this study, which lies in the nature and function of the model used. Usually, scenario planning is based on co-constructed models which help comprehend the complex nature of the systems (Etienne, 2006). These may be grouped as "companion modeling" approaches (see ComMod www.commod.org/en/), which include various forms such as conceptual models (Etienne, 2006; Étienne, 2009), multi-agent systems and modeling platforms (Bousquet et al., 1998, Bousquet et al., 2013) and role-playing models (Barreteau et al., 2002). In a "companion modeling" approach, the model brings new information at each step of the playing session to put in situation the players and see how the participants react at each step. These conceptual models enable players to draw up scenarios for the future but they do not allow their quantitative evaluation. On the contrary, the ISIS-Fish model used in this study is a spatialized quantitative complex model of fisheries dynamics built by scientists within an academic framework (Mahévas and Pelletier 2004, Pelletier et al 2009) and is only involved in the final phase of scenario planning. Unlike standard "companion models", it is not used to create the scenarios but to simulate some of their main variables thus providing quantitative projections of the evolution of the studied 

92

72 system. The purpose is to give a tangible counterpart to the narratives, by translating scenarios into quantitative assumptions and simulation settings and make the projections based on the modelled functioning of the fisheries instead of mental models.

ISIS-Fish is usually used in fisheries science to evaluate the consequences of management measures on the dynamics of species and fisheries. It is a spatial, multi-species and multi-fleet model and can be used for a wide range of applications (Gasche, 2014; Mahévas and Pelletier, 2004; Pelletier et al., 2009; Lehuta et al., 2013). This complexity makes it closer to the decision-making models used by scientific working groups. This model was selected for its availability and operational status. Furthermore, it was specifically developed to account for the spatial dynamics of the system, making it directly suitable to handle the geographic aspects of geo-foresight. Finally, parameters can easily be modified to account for new information provided by the actors. The mixed demersal fishery of the Bay of Biscay is a major structuring fishery in the area, in terms of i) landed values of the main target species hake, Merluccius merluccius, Norway lobster (Dublin Bay prawn), Nephrops norvegicus, and European common sole, solea solea., ii) management concerns (STECF, 20I5), and iii) spatial conflicts with other activities, given that the fishery operates mainly close to coast and in a major conservation area : the "Grande vasière". The ISIS-Fish application to this fishery was consequently selected to conduct the scenario evaluations.

This study examined whether ISIS-Fish, a complex quantitative model designed independently of the participatory foresight can contribute to the ambitious objective of this process, that is sharing a common vision to improve fisheries management and fisheries science. The approach is simulationbased combining qualitative and quantitative expert-knowledge to support discussion between 94 scientists and stakeholders on the functioning and the future of the demersal fishery in the Bay of 95 Biscay. A three-stage approach was carried out to address these issues : (i) translation of a narrative 
9 scenario drawn up by stakeholders into quantitative sub-scenarios that could be parameterized in ISIS-Fish; (ii) simulation and study of the consequences of the sub-scenarios on the dynamics of mixed demersal hake, Norway lobster and common sole fishery; and (iii) participants feedback on the relevance of the model, the possibility to detail the narrative scenario further and the general contribution of ISIS-Fish to geo-foresight.

\section{Materials}

\section{I Study site}

The mixed demersal fishery in the Bay of Biscay (Figure I) is fishery composed of a little more than 700 vessels over $12 \mathrm{~m}$ long. Landed value mainly distributes among hake, Norway lobster and common sole (STECF, 20I5, Leblond et al., 20I2). The fishery is characterized by the variety of fishing gear used (trawl, nets and lines), the interactions among fleets and the many technical interactions between species. The most prominent concerns trawlers activity targeting Norway lobster on the "grande vasière" which is also a nursery area for hake. This activity thus leads to numerous bycatch of juveniles hake under the legal landing size and subsequent discards. Hake, common sole and Norway lobster stocks are assessed by ICES and the fishery is subject to a number of management measures (TACs and quotas, minimum landing sizes, in the context of the hake recovery plan since 2004, the common sole management plan, a multi-species management in progress, as well as the application of framework directives (Marine Strategy Framework Directive and framework for maritime spatial planning)).

Figi: here 
A brief description of the model is given here. A more detailed description can be found in Mahévas and Pelletier (2004) and Pelletier et al. (2009). The ISIS-Fish model simulates fishery dynamics. It sets out to describe explicitly the spatial and seasonal dynamics of fishing stocks, fishing activities and regulation of access to resources. It provides information on the functioning of fisheries and evaluates fishery management scenarios.

ISIS-Fish is a mechanistic model with a monthly time step which couples three sub-models in time and space (with a variable resolution grid, Zones variable in Table I) (Figure 2):

(i) the population dynamics model describes the seasonal movement, growth, reproduction, recruitment and natural mortality for each species of the fishery (Species variables in Table I);

(ii) the fleet dynamics model describes the seasonal and spatial allocation of the fishing effort for computing the fishing mortality depending on the characteristics of the vessels, activities (métiers) and annual fishing strategies (Gear, Fishing métier, Type of trips, Type of Vessel, Fleets and Strategies, Table r); (iii) the fishery management dynamics model described the fishing limits for the fleet and the changes in fishing strategy in response to these limits (Management measures variables, Table $I$ ).

The geographic scope of the ISIS-Fish model in this study covers the whole of the Bay of Biscay (Figure I) and the spatial grid is based on ICES statistical rectangles (ICES I977). We used a first application of the ISIS-Fish model describing the demersal fisheries of the Bay of Biscay (Worsøe C. L. et al., 2016). The application was initially developed to investigate multi-species reference points based on fishing effort and to assess the impact of fishing effort reduction on fisheries dynamics and benthic habitats (Mahévas et al, 20I5). The spatial and seasonal dynamics of hake, Norway lobster and common sole mimic the life cycle of these species. The fishing activity module includes nine fleets, six French fleets and three Spanish fleets (using trawls, nets and lines), divided into sub-fleets 
I4I according to their specific annual strategies. The database used was calibrated on ICES working

\subsection{Geo-foresight}

The geo-foresight performed to "dream up" a future of the demersal fishery of the Bay of Biscay at the horizon 2050 can be described as mixed. Indeed it combines both qualitative and quantitative methods with explicit temporal and spatial dimensions. This exercise took place between April 20I5 and May 2017 and the methodology is based on surveys punctuated by three workshops for the iterative construction of scenarios. This section gives a brief description of the major aspects of the geo-foresight required for this study. For further details see Tissière et al. (2018 b) and Tissière et al. (2016). The group of stakeholders was composed of representatives of fisheries (PO representatives and the president of the regional fishing and fish-farming advisory committee) and representatives from the offshore wind farm industry. State services were also invited represented by members of the InterRegional Marine Directorate, the Marine Protected Area agency and from local authorities. Scientists from various disciplines related to marine fishing were also part of the working groups (fisheries scientists, geographers and foresight experts). All accepted the invitation with the exception of local environmental protection associations (NGOs). The modeling expert also attended the 
scenario planning workshops and took part in creating the scenarios, more as an observer than as an active contributor. The first workshop highlighted the main maritime fishing stakes of the Bay of Biscay encompassing fisheries management, cohabitation of multiple uses and environmental status. The main associated drivers characterized by trends and uncertainties were also pointed out. In the second workshop, the stakeholders drew up qualitative scenarios on the future of fishing in the Bay of Biscay up to 2050 using variables and assumptions defined during the first workshop. The stakeholders were divided into several groups and built three scenarios. The first, entitled "Jaws in the Bay”, was based on the collapse of the French interventionist model (i.e. the government lost its authority at sea in favor of private organizations). The second, entitled "Sinking fishing", was based on the break-up of the European Union, leading to the fragmentation of marine fisheries management. The third, entitled "Fishing takes on water", assumed the disappearance of towed gear and a change in the fisheries economic model with a strategic coastal organization. The quantitative study focused on the first scenario "Jaws in the Bay" (further details are available in Annex 2). The same type of approach could have been applied to the other scenarios but the time allocated to this study was too limited. A traditional foresight approach would have stopped at the end of the second workshop with a report and at best, with a restitution of the narrative form of the scenarios to the stakeholders (Figure 3). Mixing the quantitative complex model with the creation of the scenarios has led to holding a third workshop for the consultation of stakeholders involved in "Jaws in the Bay" scenario regarding the simulation work (Figure 3). Therefore this study covers the work done in between the end of the second workshop, and the third workshop of the geo-foresight.

Fig3 : here 


\section{From the narrative scenario to simulation with ISIS-Fish}

This section described the proposed approach to operate the quantitative modelling tool ISIS-fish in the geo-foresight exercise simulating one of the qualitative scenario created by stakeholders. The end of the second workshop was dedicated to the presentation of ISIS-Fish to stakeholders. The main mechanisms of the model were presented in a short video (available from isis-fish.org). The method breaks up in three steps: the translation of the "Jaws in the Bay" scenario into quantitative subscenarios (Section 3.I), the modeling and simulation of the sub-scenarios with ISIS-Fish (Section 3.2) and the presentation of the results to the stakeholders (Section 3.3).

\section{I Translating the "Jaws in the Bay" scenario into quantitative sub-scenarios}

The "Jaws in the Bay" scenario described the future of fisheries governance in the Bay of Biscay whereas the ISIS-Fish model focused on mixed demersal hake, Norway lobster and common sole fishery. Between the second and third workshops (Figure 3), stakeholders working on "Jaws in the Bay” were questioned during telephone interview to precise some points of the scenario at the scale of the demersal fishery.

First, the modeling expert and stakeholders agreed on six synthetic features structuring the scenario (Table 2): Operating mode of fishery management, Fleets, Vessels, Multiple marine uses, Controlling system, Science. Indeed, the operating mode of fishery management in "Jaws in the Bay" scenario is privatized leading to an access of maritime space and marine resources based on financial markets. Fleets are standardized through an harmonization of vessels characteristics to make economies of scale (e.g. reducing purchase price and exploitation costs). Vessels become ultra-modern and ultra-selective to meet sustainability and performance criteria of fisheries management. The cohabitation of multiple uses of the Bay of Biscay is managed by a spatial division of space into a patchwork of economic concessions to maximize the profitability of the maritime space (as illustrated 
505

in the schematic spatial representation in Annex 2). A controlling system relying on the"polluter pays" principle is established through a "sustainable fishing" charter defined based on environmental, social and financial criteria. Science becomes precarious and privatized, resulting in a scientific expertise subject to lobbying (financial and political) with an applied research dedicated to a selection of strategic topics. Only a selection of these features can be modeled in ISIS-Fish.

\section{Table 2 : here}

In a second step, the modelling expert therefore explained which features could be translated in the model using some of the structuring variables (Table I) and illustrated how using examples (Table 2). These illustrations supported by references to the video presented during the second workshop have raised questions on the meaning of general concepts used in the scenario (e.g. privatization or standardization) in the particular context of the demersal fishery of the Bay of Biscay. The decision to focus on two of the synthetic variables, Fleet and Multiple marine uses, was reached by mutual agreement considering time constraints and the risk of dispersion. During the interviews, the modeler realized that a single formulation in the narrative scenario was actually translated in multiple possible values for ISIS-Fish variables Fleets, Types of vessels, Zones and Management measures. They reflected several possible assumptions about the functioning of the fishery, that were not detailed in the narrative but needed to be made all explicit in the model to avoid biasing the initial "Jaws in the Bay" scenario. This required the modeling expert to go back to the stakeholders for further precise these four variables and limit the number of possible assumptions and subsequent simulations. Regarding the Fleet variable (Table 2) the assumptions concerned the level at which standardization applied. Does it apply to the type of fishing (coastal, mixed, deep-sea)? Does it apply to the equipment (engine power, selectivity, length of vessel)? Stakeholders agreed on considering four options: a base case without standardization implying to keep all the vessels in the fishery as they 
561234 are (“all vessels”), and three schematic declinations of standardization consisting in keeping 563235 alternatively one or two of the three existing segments of the fleet identified according to vessel length 565236 ("vessels of length I2m - I8 m", "vessels over I8 m long”, "vessels less than I2 $\mathrm{m}$ and more than I8 $\mathrm{m}$ 567237 long”). The description of the Multiple marine uses variable raised the following questions: Are the economic concessions localized on the coast, the continental shelf or deep-sea? Is fishing allowed within the other economic concessions or is it pushed further offshore? Stakeholders considered a drastic spatial planning of marine uses localizing other uses than fishing within a coastal zone (called restricted zone "RZ", and referring to the patchwork in the schematic spatial representation in Annex 2), banning fishing in this zone and pushing fishing activities offshore.

Crossing these assumptions, the stakeholders drew up four sub-scenarios derived from the initial "Jaws in the Bay" scenario that could be parameterized in the ISIS-Fish model: JB I, JB 2, JB 3 and JB 4. All included a fishing ban in the RZ zone. The difference between the sub-scenarios depended on the length of the vessels allowed to fish. The JB quantitative sub-scenarios were:

$\mathrm{JB} \mathrm{I}=\mathrm{RZ}+$ vessels of length $\mathrm{I} 2 \mathrm{~m}-\mathrm{I} 8 \mathrm{~m}$

$\mathrm{JB} 2=\mathrm{RZ}+$ vessels over $\mathrm{I} 8 \mathrm{~m}$ long

$\mathrm{JB}_{3}=\mathrm{RZ}+$ vessels less than $\mathrm{I} 2 \mathrm{~m}$ and more than $\mathrm{I} 8 \mathrm{~m}$ long

$\mathrm{JB}_{4}=\mathrm{RZ}+$ all vessels

Before banning fishing activities from RZ, most vessels were fishing in this zone. The establishment of the ban has required modelling a fishermen reaction through a reallocation of fishing effort. Stakeholders agreed to consider that fishermen comply with the regulation and report their activity outside the ban on their remaining fishing zone (i.e. their usual fishing zone - RZ zone). RZ zone is close enough to the coast so that the remaining area for fishing is not empty and does not induce a stop of fishing in the fishery. The four sub-scenarios were then simulated using ISIS-Fish, limiting 
617257 the active fleets described in ISIS-Fish to the standardized lengths and using the closing fishing area 620258 management option available in the simulation tool to ban fishing in the RZ zone.

\subsection{Simulations of sub-scenarios}

Simulations started in 2010 (model parameterization reference year) and lasted for 40 years to study the change in fisheries over the scenario period (2015-2050). The simulation took an average of 40 minutes. Each simulation corresponded to a quantitative sub-scenario based on the qualitative "Jaws in the Bay" scenario and, therefore, to a particular development path for the fisheries. The study considered the spatial and temporal changes in the populations of hake, Norway lobster and common sole and the fleets in the Bay of Biscay. There were four output variables: biomass, catch, fishing mortality and fishing effort.

The results were presented at the third foresight workshop (Figure 3). The video of ISIS-Fish functioning was played again to facilitate the understanding of the translation of the "Jaws in the Bay” scenario into quantitative sub-scenarios and the simulations outputs. Then the four subscenarios were presented orally and the overall trends of the results were described.

\subsection{Global description of outcomes}

Figure 5 shows the change in biomass, fishing mortality and catch for hake, common sole and Norway lobster, for each JB sub-scenario for the period 20I0-2050. The biomass increased over the period 20I0-2050 for each of the three species. Once stable, the biomass for the hake and common sole had tripled and that of the Norway lobster was six times greater in 2050 . The biomass of the hake and common sole stabilized rapidly (i.e. in 2017 and 202I respectively) whereas the biomass of the Norway lobster increased progressively and tended to stabilize in 2050. The transitory phase for the common sole biomass between 2010 and 2016 (Figure 5 and Figure 6b) was due to the recruitment 
which was forced to values assessed by the ICES working group for this period then replaced by a stock recruitment relationship (ICES, 20I4). The changes in fishing mortality and catch depended on the scenario and the species. The fishing mortality stabilized at values higher than the initial values for hake while it dropped to values close to zero for Norway lobster and common sole. The catches followed roughly the same trends as the fishing mortality. They were constant for hake and tended towards zero for the Norway lobster and common sole.

Figs : here

\subsubsection{General trends and Spatial dimension of sub-scenarios}

Using global models (e.g. Schaefer, 1954) with an annual time step and no spatialization, an increase in abundance, or biomass, leads to an increase in catch if the fishing mortality is constant (Pelletier and Mahévas 2005). Using ISIS-Fish, this trend was not found for Norway lobster or common sole (figure 5) for any of the sub-scenarios. This behavior was explained by the non-linear effect of biomass on fishing mortality and catches due to the uneven spatial distribution of the biomass and fishing effort. For sub-scenario JBI (Figure 6) in particular, the change in biomass for Norway lobster and common sole is shown for each statistical rectangles. For Norway lobster, rectangles ${ }_{23} \mathrm{E} 6$ and $23 \mathrm{E} 5$ stand out with a considerable increase in biomass up to 2050 , reaching more than 70 thousand tones. Rectangles $22 \mathrm{E}_{7}$ and $24 \mathrm{E} 6$ display an increase in biomass three times greater than rectangles ${ }_{23} \mathrm{E} 6$ and $23 \mathrm{E} 5$. The biomasses of the five remaining rectangles tend towards zero over the period Figure 6). The rectangles where the biomass increases are those covered by the area restriction $\mathrm{RZ}$. The same trends are found for common sole (Figure $6 \mathrm{~b}$ and $6 \mathrm{~d}$ ). The north and south coastal zones are completely covered by an area restriction $\mathrm{RZ}$ resulting in increasing biomass. On the contrary, the biomass in the central coastal zone tends towards zero after 2015 although four fifths of the zone is covered by the area restriction RZ. Indeed, the ISIS-Fish model assumes that, if the 
intersection between a fishing zone and a population zone is not empty, the fishing effort allocated to the intersection applies to all the fish in the population zone. This reflects the assumption that a mobile species does not remain localized in a small part of the population zone but, over a month, moves uniformly throughout the zone. Consequently, for common sole, the restriction reduces the fishing effort applied to the central coastal zone population but does not protected it. Still overall, (Figure 5), the biomass increases. The fishing mortality and catches decrease as there is only one rectangle where common sole can be targeted, resulting in very low fishing pressure and very low catches. The reductions are less marked for Norway lobster as more rectangles where the lobster is found remain open to fishing.

Fig 6 : here

\subsubsection{Sub-scenario specificities interpretation}

The biomass increased for the four sub-scenarios for all species (Figure 5). For Norway lobster and common sole, the dynamics of sub-scenario JB 4 were significantly different from the other subscenarios before stabilization, whereas, for hake, the dynamics for all the scenarios had a similar form but reached different equilibrium values. These results should be viewed in relation with the fishing effort associated with each scenario (Table 3 ) and its spatial distribution depending on the specific fishing grounds of each fleet segments. Overall, the greater the number of vessels, the greater the fishing effort and the lower the biomass. The values for the fishing effort given here are those when the model has reached equilibrium and have become constant over time. 
Simulation outcomes showed that given a particular narrative story at the scale of the socio-ecosystem of the Bay of Biscay, the quantitative model ISIS-fish can drew up several separate futures of the demersal fishery. The standardization of fleets through the homogenization of vessels types to reduce costs and the spatial organization of maritime uses lead at the horizon 2050 to different paths of fleets and biomass of targeted species evolution. The discrepancies between paths can be explained on one hand by the changes in the number of vessels and the associated change in fishing power, but also by spatial heterogeneity of fishing activities and targeted species in the Bay of Biscay, that only a spatially explicit model can anticipate.

\subsubsection{Feedback from stakeholders regarding the model and model outputs}

Unlike standard scientific slide presentations a within the context of meeting involving scientists and various stakeholders, we opted for a video of science popularization for fishing actors to present ISIS-Fish. The schematic of the model and its components enabled the actors to visualize the functioning of the model fairly easily (i.e. interactions of the three sub-models, monthly time step, spatialization and seasonality of the processes). They appeared very receptive to this format and expressed their understanding of the ins and outs of model, of its interest in simulating the dynamics of mixed fisheries and how it should be used. This was also well illustrated during the telephone interview with the sub-group of stakeholders involved in "Jaws in the Bay" scenario, facilitating the discussion thanks a common understanding of modelled processes and vocabulary used to describe them. The actors had understood the structural variables that the modeler can varied. It was therefore easier for the modeler to focus the suggestion of requested precisions on assumptions identified in the 
84134

$842^{34}$

843349

845350

$8466^{35}$

847351

848

849352

850

851353

852

853354

854

855355

856

857356

858

859357

860

861358

862

863359

864

865360

866

867 36I

868

869362

870

871363

872

873364

874

875365

876

877366

878

879367

880

$881^{368}$

882

scenario and to reach the agreement of the examples presented in Table 2. The interfaces designed for the parametrization of ISIS-Fish were presented to stakeholders and also helped in the design of the sub-scenarios. Indeed it demonstrated how easily parameter values can be modified with the evolution of knowledge or simply to test different hypotheses. This part of the presentation raised many questions about the origin of the values, how they were estimated, what data were used. But it was also an opportunity to show that the model was feeding on the knowledge available on marine species and fishing activity evidencing the valorization of both declarative data and scientific surveys. This data-driven transparent approach was highly appreciated and the flexibility of the model induced by user-friendly interfaces to test new values of parameters was well understood and makes it as easy to consider that the spatial location of the activities assumed in the "Jaws in the Bay" scenario could be integrated in ISIS-Fish by changing the fishing areas and adding a fishing ban area.

The presentation of the defined four sub-scenarios to the stakeholders not involved in the "Jaws in the Bay" scenario has raised debates on the coherence between the sub-scenarios and the "Jaws in the Bay" scenario rather than on the model outputs. For example, the fleet standardization variable was translated into a selection of certain fleets, in other words by the disappearance of the other fleets. The stakeholders stressed that the translation of this hypothesis was not an exact match for the vision of the "Jaws in the Bay" scenario. For example, they proposed changing the number of vessels in the remaining fleets to maintain a constant number of boats.

On the contrary to the two previous steps, the presentation of the simulation outputs did not raise much discussion. However some of the counter intuitive results were more deeply investigated and explained in order to evidence the mechanisms, often spatial interactions, responsible. These examples seemed to raise stakeholder awareness of the many interactions involved which can possibly make projections derive from their mental model. Unlike traditional scenario simulations, the analysis is not a comparative analysis to a reference scenario corresponding to the « business as 
usual » evolution of the system (Lehuta et al, 2013). Here we seek to compare possible evolutions of the system within the future dreamed up in the "Jaws in the Bay" scenario far from the current situation of functioning of the system. The objective is to provide concrete quantitative illustrations of what this virtual scenario could be at the downscale of the fishery. The use of the ISIS-fish tool, which is close to management and decision-support tools gives a more decision-making and management dimension to the foresight exercise. The actors seemed to give credit to the outputs of the model.

\section{Discussion}

This study set out to use the ISIS-Fish model as a support for the collaboration in the construction of scenarios for fisheries management in the Bay of Biscay. It showed that the lack of collaboration in building the model (which was conceived by academics), contrary to recommendations for participatory approaches (Etienne 2006, Étienne, 2009; Bousquet et al., 1998, 2013; Barreteau et al., 2002), was offset by a good appropriation of model assumptions through the movie and an appropriate parametrization for the Bay of Biscay. The use of the ISIS-Fish model in this study was justified both by its structural characteristics and for practical reasons.First, the aim of foresight is to anticipate changes in fisheries management and ISIS-Fish is a quantitative model that is able to produce information on the consequences of fishing management scenarios. It has been largely argued that Decision Support Tool (especially for Marine Spatial Planning) should consider spatial and temporal dynamics, be easy to use and free available, and assist operational process of management (Pinarbasi et al 2017). The spatially explicit aspect of ISIS-Fish, a keystone of geoforesight, was thus an advantage. Secondly, there was an off-the-shelf parameterization of the ISISFish model for the Bay of Biscay mixed hake, Norway lobster and common sole fishery which was 
central to the governance considered in the scenario planning. Thirdly, the interfaces within the ISISFish system provided considerable flexibility for testing alternative parameters and comparing different visions of the fishery. Even if stakeholders were not involved in model building itself, they worked in close cooperation with the modeler for implementing the scenario in ISIS-Fish. The "Jaws in the Bay" scenario was built entirely by the stakeholders and it was translated with their assistance into quantitative sub-scenarios for simulation using ISIS-Fish. The model was evaluated and discussed with the stakeholders and the coherence of the simulations with the JB scenario was verified by the stakeholders. It is well-known that transparency and participatory process facilitate and structure discussion between scientists and actors (Stelzenmuller et al 2013). Modelling should not be seen as a priority but rather as a tool to trigger discussions. Here the necessary explanation of subscenarios results clearly contributed to collective learning (Röckmann et al 2oI2).

Discussion between the stakeholders about the ISIS-Fish model began with the presentation of the model. A complex quantitative model, regardless of how complex it is, must be presented using easily understood terminology and with maximum clarity . Sharing a common language and vision contribute to trust in fisheries community (Glenn et al 20I2). In this study, the simplified presentation using a video established a good relationship between the modeling experts and the stakeholders. Several questions emerged from the discussions and indirectly informed on important aspects of their activity they felt needed to be modeled. What degree of precision is required to enable qualitative scenarios to be translated into quantitative scenarios? How many variables can the model handle? Can it handle variables exogenous to fishing such as changes in fuel? The model was seen as a representation of the fishery under study, that participants were free to criticize and improve to make it closer to their own vision. This study showed that a quantitative model is an effective means of strengthening participation and that quantitative and qualitative approaches must be combined. 
ISIS-Fish proved to be a basis for constructive criticisms to refine the JB scenarios in the mixed demersal fishery compartment of the Bay of Biscay. The transition from qualitative to quantitative required the definition of the processes and variables to be modified and parameterized (i.e. rules to be applied, fleets selected and restricted zone defined). This stage required several assumptions to be made, in particular due to the inherent lack of precision in the terminology used for the qualitative scenario. Joint discussions with the stakeholders enabled fitting the model closely to their perception. For instance, the Fleet standardization variable was translated by selecting certain fleets, causing the disappearance of other fleets. During the report workshop, the stakeholders who were not consulted questioned the translation of this assumption, finding that it was simplistic and was rather farremoved from their vision of the "Jaws in the Bay" scenario. They proposed alternative means of translating the scenario and additional assumptions (e.g. varying the proportions of the fleets). This critical feedback reflects the importance of the translation stage involving the stakeholders and of the wide variety of possible declination of a qualitative scenario into quantitative ones. This also led the stakeholders to consider the functioning of the mixed hake, Norway lobster and common sole fishery in greater detail. During this stage, the modeling experts noted that there were differences in the terminology used by members of the fishing industry, reflecting also the different visions of stakeholders (D'Aquino et al., 2002). The translation stage enabled the stakeholders of the "Jaws in the Bay" scenario to define a common terminology and share a common vision (Glenn et al 2or2).

The presentation of the quantitative results of the effect of fleet standardization and displacement of the fishing further offshore to allow other activities by humans led to discussion on the perception of the functioning and in particular the spatial interactions between the dynamics of the fish populations and human activities at sea. The results showed that the area restriction RZ had a great effect on the fishery dynamics. Moving fishing further offshore to allow the establishment of fixed activities such as aquaculture, offshore wind farms and the extraction of aggregate relieved the 
common sole nurseries of fishing pressure and allowed them to grow. However, potential impact of these new coastal activities on the three species was not considered in the model. Furthermore, the drastic reduction in Norway lobster and common sole catches near the coast led to the disappearance of certain coast-based fishing métiers and the transfer of the effort to other fishing métiers which considerably modified the nature of fishing. Discussions with the stakeholders showed that it might be possible to reorganize concessions in the coastal zone to assign some to fishing and suggested adding or testing hypotheses regarding the impact of activities other than fishing on the dynamics of common sole and Norway lobster. This exercise demonstrated the importance and feasibility of including spatial variations in foresight.

The discussions following the presentation of the results revealed the initial value of this exercise for the various stakeholders (van Hoof et al 2014). Firstly, unlike the usual meetings attended by stakeholders, there was no high economic or management stakes, and these workshops provided the opportunity for discussing and confronting ideas and representation of the system functioning and evolution. Discussion threw light on quantitative models for fisheries stakeholders. There was critical feedback from the stakeholders on the accessibility of the model, the coherence of the results and the use of the model for scenario planning. The quantitative model, which was similar to the models used for evaluation by scientific working groups (ICES, STECF), was compared with the vision stakeholders have, which is not usually the case in decision-making processes (Lehuta et al 2016). This approach facilitates the transfer of information on fisheries management and increases collaboration between stakeholders and modellers (Opdam, 20ro). It also contributed to legitimate complex models and moves forward improving fisheries science and management (Glenn et al 20I2). In this case, fisheries system stakeholders produced relevant input for both modeling and management strategies. 
While the ISIS-Fish model was considered appropriate for the exercise for the reasons exposed above, a few limits of the current settings were highlighted. The current spatial resolution (a cell = Ices rectangle $=60$ nautical miles $\times 30$ nautical miles) for parameterizing the hake, Norway lobster, common sole fishery is not ideal for dealing with a certain number of problems. During discussions between the stakeholders on the "Jaws in the Bay" scenario, the problem of the extend of the restricted zone was raised since the I2 nautical miles coastal strip (i.e. limit of territorial waters) is much narrower than the model spatial resolution. Although this problem was overcome by designating the coastal zone as a restricted area, it would be useful to propose a finer resolution. Realistically, on the basis of available information, (e.g. Vessel Monitoring System for fishing effort, Scientific surveys for population distribution), it could be an $1 / 8^{\text {th }}$ of the statistical rectangle. Temporal scale on the other hand was considered appropriate. Foresight prepares for a distant future (De Jouvenel and Fish, 2004; Mermet, 2005; Michel, 2007). This requires a model able to carry out long-term simulations, as is the case for ISIS-Fish given its mechanistic nature. This is an asset which had never before been explored in studies using ISIS-Fish which tended to analyze the transition phase in changing fishing dynamics (e.g. Gasche et al 2013; Lehuta et al 2013b). Furthermore, scenario planning in foresight must take account of all possible changes and depletions of stocks (De Jouvenel and Fish, 2004; Mermet, 2005; Michel, 2007). The model must be able to simulate these changes. A major advantage of ISIS-Fish is its flexibility in programming processes. It was designed to be able to study a wide variety of fisheries (e.g. single species / multi species, single fleet / multiple fleets, large / fine spatial and temporal resolution) and be able to change certain assumptions easily.

It would have been interesting to go further in the analysis till the translation of model runs into the socio-economic context (Bellanger et al. 20I8, Le Floc'h et al. 2015). However the time duration constraints of the geo-foresight (induced by the COLSELMAR research project supporting this 
study) did not allow for assessing the consequences of change in catch and biomass of the three targeted species of the fishery using social and economic indicators.

\section{Conclusions and future developments}

To our knowledge, this is the first time a complex spatial quantitative model such as ISIS-Fish is used for foresight. This study showed that the model and its results could be integrated into the approach and aroused interesting discussion on the synergy between complex modeling and scenario planning. Without ISIS-Fish, the participatory process would have ended with the second workshop and would have only delivered three narrative scenarios (like the JB scenario described in Annexer). The ISIS-Fish model has enabled I) to describe one of these scenarios at the scale of the demersal fishery, 2) to show that several hypotheses of mechanisms of fishery dynamics could be derived from the narrative scenario and 3) to demystify complex models supporting fishing management through discussion about the model and its inputs.

The qualitative scenarios formed the basis for modeling and the ISIS-Fish results expanded these scenarios with quantitative information. The advantage of mechanistic models such as ISIS-Fish is their ability to consider complex processes and the interactions between them, sometimes highlighting unexpected chain reactions. The simulation results showed the relevance of using a spatial model to explore the changes induced by the various sub-scenarios.

This study also had the advantage to present to stakeholders a spatialized fishing management model similar to those used by scientific working groups. The management models used for fisheries science are often complex and appear to be black boxes to most uninitiated (Link et al 2oro, Lehuta et al 2016). Stakeholders tend to reject both models and results assuming their functioning is inaccessible. This causes even more problems when it is these uninitiated who are mainly concerned by the consequences of management measures. This study is, therefore, an initial step towards 
making complex models and decision-making processes more transparent and acceptable and proving this is doable. This approach comes close to participatory fisheries research which has great potential for maritime fisheries (Wiber et al., 2009). It could reduce the gap between the stakeholders, scientists and decision-making bodies

The results of this study provide support for the use of the ISIS-Fish model for geo-foresight. Its flexibility enables it to model and simulate environmental scenarios. Using the model for geoforesight could also be considered for research rather than policy by alternating description of the system and modeling during scenario planning, like a research/training/policy system (Lardon et al., 2008). This would train stakeholders in quantitative modeling and increase the relevance and synergy between the two approaches. Furthermore, even if some disappointment or tension arised during the modeling phase, mostly related to some simplistic features in sub-scenarios, they should not be viewed as a failure but rather as normal evolution in the development of the concept. Levin et al (2018) referred to the "hype cycle" described for emerging technologies to describe the phases of development and the acceptance of new fisheries assessment models. According to this theory, the adoption of a new technology (here a model), follows phases of high expectations and disillusionment, that will ultimately be followed by a slope of enlightenment and a plateau of productivity. This should encourage collective perseverance in combining quantitative and qualitative approach.

Finally, although this study did not intend to build probable or strategic scenarios we are confident that the richness of the input by stakeholders would sufficiently strengthen the input data and mecanisms (e.g. social processes) to make this objective realistic. It already proved efficient in improving the relationship between the stakeholders and fishery scientists, which might have been tensed historically. As one of the stakeholders commented, actors increasingly realized that their 
future somehow depends on the results of these strategic model results, and it is their own interest to help making them more robust and realistic.

\section{Aknowledgments}

This work was supported by grant from the Regional Council of the Pays de la Loire (Convention COSELMAR 20I2-09684) and from Ifremer (Project APPELS). We would like to thank all stakeholders who participated to the geo-foresight and who critically facilated this work. Many thanks to the three anonymous reviewers for their comments, which greatly improved an earlier version of the manuscript.

\section{References}

Barreteau, O., Aquino, P. d., Bousquet, F., Le Page, C., 2002. Le jeu de rôles à l'interface entre systèmes réel et virtuel pour la gestion de ressources renouvelables: exemples d'application au Sénégal. In Orange Didier (ed.), Arfi Robert (ed.), Kuper M. (ed.), Morand Pierre (ed.), Poncet Yveline (ed.), Témé B. (préf.) Gestion intégrée des ressources naturelles en zones inondables tropicales. Paris (FRA); Bamako : IRD ; CNRST, 799-814.

Bellanger M., Macher C., Merzereaud M., Guyader O., Le Grand C. 20I8. Investigating trade-offs in alternative catch-share systems: an individual-based bio-economic model applied to the Bay of Biscay sole fishery. Canadian Journal of Fisheries and Aquatic Sciences. In press.. Publisher's official version : http://doi.org/ı.II39/cjfas-2017-0075,

Biais, G., 1993. La gestion des pêches par contingentement des captures dans le nord-ouest de l'Europe. In: Les recherches françaises en évaluation quantitative et modélisation des ressources et 
des systèmes halieutiques. Premier Forum Halieumétrique, ORSTOM éditions, Paris. pp. 309 320.

Bousquet, F., Bakam, I., Proton, H., Le Page, C., 1998. Cormas: common-pool resources and multiagent systems. In: Tasks and Methods in Applied Artificial Intelligence. Springer, pp. 826837 .

Bousquet, F., Barreteau, O., Mullon, C., Weber, J., 20I3. Modélisation d'accompagnement: systèmes multi-agents et gestion des ressources renouvelables. Indisciplines, I47 I55.

Caddy, J., Mahon, R., 1996. Points de référence en aménagement des pêcheries. FAO Document technique sur les pêches (347).

D'Aquino, P., Barreteau, O., Etienne, M., Boissau, S., Aubert, S., Bousquet, F., Le Page, C., Daré, W., 2002. The role playing games in an abm participatory modeling process: outcomes from five different experiments carried out in the last five years. In: Integrated assessment and decision support. iEMSs. Ist biennial meeting of the International Environmental Modelling and Software Society, Lugano, Switzerland. pp. 2427.

De Jouvenel, H., Fish, H., 2004. Invitation à la prospective. Futuribles. Ed. Perspectives. 90.

Étienne, M., 2009. Co-construction d'un modèle d'accompagnement selon la méthode Ardi: guide méthodologique. Cardère Éditions, Laudun. 7ıpp.

Etienne, M., 2006. La modélisation d'accompagnement: un outil de dialogue et de concertation dans les réserves de biosphère. Biodiversité et acteurs : des itinéraires de concertation. 2006, 44-52

Fulton, E. A., Link, J. S., Kaplan, I. C., Savina-Rolland, M., Johnson, P., Ainsworth, C., Horne, P., Gorton, R., Gamble, R. J., Smith, A. D., et al., 2orI. Lessons in modelling and management of marine ecosystems: the Atlantis experience. Fish and Fisheries I2 (2), I7I I88.

Gasche, L., 20I4. Élaboration d'un diagnostic robuste de mise en place d'aires marines protégées, dans un contexte d'incertitudes, elaborating a robust mpa diagnostic in a context of uncertainty. Ph.D. thesis, Université Européenne de Bretagne, Agrocampus Ouest, Rennes. 
Gasche, L., Mahévas, S., et Marchal, P. 2013. Supporting fisheries management by means of complex models: can we point out isles of robustness in a sea of uncertainty? Plos One 8, (IO), I-I4.

Gascuel, D.G.D., Bez, N., Forest, A., Guillotreau, P., Laloe, F., Lobry, J., Mahevas, S., Mesnil, B., Rivot, E., Rochette, S. and Trenkel, V., 20II. A future for marine fisheries in Europe (Manifesto of the Association Francaise d'Halieumetrie). Fisheries Research I09, I-6.

Glenn, H., Tingley, D., Sánchez Maroño, S., Holm, D., Kell, L., Padda, G., Runar Edvardsson,I., et al. 2012. Trust in the Fisheries Scientific Community . Marine Policy 36, no I: 54-72.

Godet, M., 200I. Manuel de prospective stratégique: l'art et la méthode. Dunod. 293pp.

Gourmelon, F., Houet, T., Voiron-Canicio, C., Joliveau, T., 20I2. La géoprospective, apport des approches spatiales à la prospective. L'espace géographique 4I (2), 9798.

Houet, T., Gourmelon, F., 20I4. La géoprospective apport de la dimension spatiale aux démarches prospectives. Cybergeo: European Journal of Geography. DOI : I0.4000/cybergeo.26194

ICES, 1977. CM document 1977/Gen:3 document 'ICES Statistical Rectangle Coding System'.

ICES, 20I4. Report of the working group for the Bay of Biscay and the Iberian Waters Ecoregion (WGBIE). ICES CM 20I4/ACOM : II., 7-I3 May 20I4, Lisbon, Portugal 748.

ICES, 20I5. Report of the Working Group for the Bay of Biscay and the Iberian waters Ecoregion (WGBIE). ICES CM/ACOM:II, O4-Io May 20I5, Copenhagen,Denmark, 503.

Kahn, H., and A. J. Wiener. 1967. The year 2000: a framework for speculation on the next thirtythree years. Macmillan, New York.

Leblond E., Daures F., Berthou P., Merrien C., Pitel-Roudaut M., Le Grand C., Demaneche S., Jezequel M., Bodere E., Le Blond S., Macher C., 20I2. Synthèse des flottilles de pêche 2oro. Flotte de Mer du Nord - Manche - Atlantique. Flotte de Méditerranée . 292pp. http://archimer.ifremer.fr/doc/ooli7/22797/ 
Le Floc'h P., Murillas A., Aranda M., Daures F., Fitzpatrick M., Guyader O., Hatcher A., Macher C., Marchal P. (20I5). The regional management of fisheries in European Western Waters . Marine Policy, 51, 375-384

Lehuta, S, Girardin, R., Mahévas, S, Travers-Trolet, M., Vermard, Y. 2016. Reconciling complex system models and fisheries advice: Practical examples and leads. Aquat. Living Resour. 29 (2) 208

Lehuta, S., Petitgas, P., Mahévas, S., Huret, M., Vermard, Y., Uriarte, A., Record, N. R., 2013. Selection and validation of a complex fishery model using an uncertainty hierarchy. Fisheries Research I43, 5766.

Lehuta, S., Mahévas, S., Petitgas, P., et LeFloch, P. 2013b. A simulation-based approach to assess sensitivity and robustness of fisheries management indicators for the pelagic fishery in the Bay of Biscay. Can. J. Fish. Aquat. Sci., 70, 174I--1756.

Lequesne, C., 1999. Quand l'union européenne gouverne les poissons: pourquoi une politique commune de la pêche? Etudes du CERI (6I), I 36.

Levin, Phillip S., Timothy E. Essington, Kristin N. Marshall, Laura E. Koehn, Lee G. Anderson, Alida Bundy, Courtney Carothers, et al. « Building Effective Fishery Ecosystem Plans ». Marine Policy 92 (juin 2018): $48-57$.

Link J.S., Ihde T.F., Townsend H.M., Osgood K.E., Schirripa M.J., Kobayashi D.R., Gaichas S.K., Field J.C., Levin P.S.,Aydin K.Y., others, 2oro, Report of the 2nd National Ecosystem Modeling Workshop (NEMoW II): Bridging the Credibility Gap Dealing with Uncertainty in Ecosystem Models. US Department of Commerce, National Oceanic and Atmospheric Administration, National Marine Fisheries Service.

Linke, S., and Bruckmeier, K., 20I5. Co-Management in Fisheries - Experiences and Changing Approaches in Europe. Ocean \& Coastal Management 104 : 170-8I. 
Mackinson, S., Wilson, D. C. K., 20I4. Building bridges among scientists and fishermen with participatory action research, I2I 139 .

Mahévas, S., Pelletier, D., 2004. ISIS-Fish, a generic and spatially explicit simulation tool for evaluating the impact of management measures on fisheries dynamics. Ecological Modelling ${ }^{171}$ (I), 6584 .

Mahévas, S., Lehuta, S. and Laffargue, P. (2015) Beyond the single species Maximum Sustainable Yield approach: a multiple species and multiple fleets approach using the ISIS-fish simulation tool. Symposium on "Targets and limits for long term fisheries management". October 2ors. Athenes.

Mermet, L., 2005. La prospective générale: des ressources à mobiliser pour les recherches environnementales. Étudier des écologies futures. Un chantier ouvert pour les recherches prospectives environnementales. PIE-Peter Lang, EcoPolis ( 5 ).

Michel, G., 2007. Manuel de prospective stratégique. Une indiscipline intellectuelle I. Dunod. 279pp.

Opdam, P., 20IO. Learning science from practice. Landscape Ecology 25 (6), 82I 823.

Pelletier D., Mahévas S. 2005. Fisheries simulation models for evaluating the impact of management policies, with emphasis on marine protected areas. Fish and Fisheries. 6 (4):307-349.

Pelletier, D., Mahevas, S., Drouineau, H., Vermard, Y., Thebaud, O., Guyader, O., Poussin, B., 2009. Evaluation of the bioeconomic sustainability of multi-species multi-fleet fisheries under a wide range of policy options using ISIS-Fish. Ecological Modelling 220 (7), IOI3 1033.

Peterson, G.D., Cumming, G.S., Carpenter, S.R. 2003. Scenario Planning: a Tool for Conservation in an Uncertain World Conservation Biology, Pages 358-366. Volume 17, No. 2, April 2003 
Pınarbaşı, K., Galparsoro I., Borja, A., Stelzenmüller, V., Ehler, C. N., Gimpel, A. . 2017. Decision Support Tools in Marine Spatial Planning: Present Applications, Gaps and Future Perspectives . Marine Policy 83: 83-9I.

Röckmann, C., Ulrich,C., Dreyer, M., Bell, E., Borodzicz,E., Haapasaari, P., Hiis Hauge, K. et al. 20I2. The Added Value of Participatory Modelling in Fisheries Management - What Has Been Learnt? Marine Policy 36, no 5: 1072-85.

Schaffer, M. B.,1954. Some aspects of the dynamics of populations important to the management of the commercial marine fisheries. Bull. Inter-Amer. Trop. Tuna Comm.,I, no 2, pp. 26-56.

STECF, 20I5. Multiannual management plans sww and nww(stecf-I5-08). EUR 27406 EN, JRC 96964, 82pp.

Stelzenmüller, V., Lee, J., South, A., Foden, J., Rogers, S.I..2or3. Practical Tools to Support Marine Spatial Planning: A Review and Some Prototype Tools. Marine Policy. 38: 214-27.

Stephenson, R. L., Paul, S., Pastoors, M. A., Kraan, M., Holm, P., Wiber,M., Mackinson,S., Dankel, D.J., Brooks, K., Benson, A. 2016. Integrating Fishers' Knowledge Research in Science and Management. Ices Journal of Marine Science 73, no.

Tissiere L., Mahevas S., Trouillet B. (2018a) Findings from an exploratory study on the governance of a French fishery. Marine Policy In Press. http://doi.org/ıo.IoI6/j.marpol.20I8.oI.o28

Tissiere L., Michel C., Trouillet B., Mahevas St. (2018b). La géoprospective: une rencontre entre géographie et prospective ? Expérimentation sur les pêches maritimes du Golfe de Gascogne . Développement Durable et Territoires. In press.

Tissiere L., Mahevas S., Michel C., Trouillet B. (2016), Les pêches maritimes, un terrain d'expérimentation de la géoprospective, Les Cahiers de géographie du Québec, vol. 6o, n 70 . 
162576 Thébaud, O., Doyen, L., Innes, J., Lample, M., Macher, C., Mahevas, S., Mullon, C., Planque, B., ${ }_{1627} 63$ Quaas, M., Smith, T., et al., 20I4. Building ecological-economic models and scenarios of marine 162974 1630

van Hoof, L., 20I5. Fisheries management, the ecosystem approach, regionalisation and the elephants in the room, Marine Policy, 60, 20-26

van Hoof, L., Hendriksen,A., Bloomfield, H. J., 20I4. Sometimes you cannot make it on your own; drivers and scenarios for regional cooperation in implementing the EU Marine Strategy Framework Directive, Marine Policy, 5o (B), 339-346

van Hoof, L., van Leeuwen,J., van Tatenhove, J. 20I2. All at sea: regionalization and integration of marine policy in Europe. Maritime Studies II :9.

Wiber, M., Charles, A., Kearney, J., Berkes, F., 2009. Enhancing community empowerment through participatory fisheries research. Marine policy 33 (I), I72 179.

Worsøe C. L. et al. (2016). Myfihsh d2.4 _ Scientific advances on msy and the implications for management. Deliverable month 48. Myfish European Project. Framework Programme $\left(\mathrm{FP}_{7} / 2007-2013\right)$ under grant agreement n 289257 
Figure I. Mixed Hake, Norway lobster and common sole fishery study area (sub zone VIIIab, ICES)

Figure 2. Overview of the model decomposed into three sub-models, adapted from Mahévas and Pelletier (2004). The ovals correspond to the sub-models which interact in time and space (Zones variable in Table I). Intersection $\mathrm{I}$ is the relationship between the fishing effort and the population distribution, and fishing mortality. Intersection 2 is the dynamic distribution of the fishing effort as a response to fishery management measures and intersection 3 is the fishery management dynamics in response to the status and distribution of fish populations and fleets.

Figure 3. Organization of the scenario planning into three workshops with all the players and a step implementing the ISIS-Fish model.

Figure 4. General flowchart : $S$ is the scenario. $S_{A}, S_{B}$ and $S_{C}$ represent the three scenarios produced by the scenario planning workshops. Scenario $S_{A}$ is the "Jaws in the Bay" scenario and $\mathrm{S}_{\mathrm{Al}}, \mathrm{S}_{\mathrm{A}_{2}}, \mathrm{~S}_{\mathrm{A}_{3}}$ and $\mathrm{S}_{\mathrm{A}_{4}}$ are the four sub-scenarios. The red boxes represent the translation stages converting the qualitative scenarios into quantitative scenarios that could be modeled in ISIS-Fish. The grey boxes are the stages for the simulation and presentation of the results at the following workshop.

Figure s: Change in biomass, fishing mortality and catches for each of the $4 \mathrm{JB}$ sub-scenarios for each species. The biomass and catches are in thousands of tonnes and the fishing mortality varies from o to I. The biomass is the biomass in January each year, the fishing mortality is the mortality for each type of fish each year in December and the catch is the total catch for each year.

Figure 7. (a) (b) Change in biomass (in thousands of tonnes) for Norway lobster and common sole as a function of the population zones defined in the ISIS-Fish model for subscenario JB I. (c) (d) Maps showing the location of each population where RZ is the restriction zone. For Norway lobster, the curves correspond to the statistical rectangles (e.g. ${ }_{2 \mathrm{IE}}$ ), whereas, for common sole, the curves and fishing zones are color coded. Only subscenario JB $\mathrm{I}$ is shown as the trends for all scenarios are similar. 


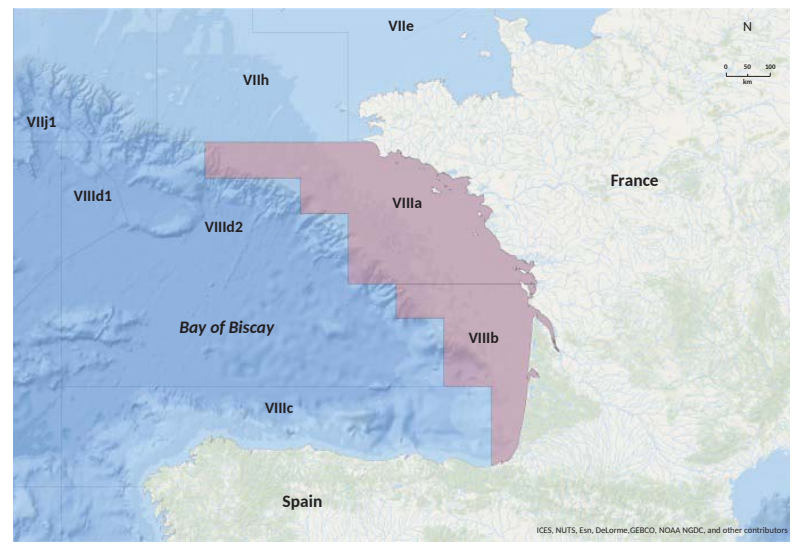




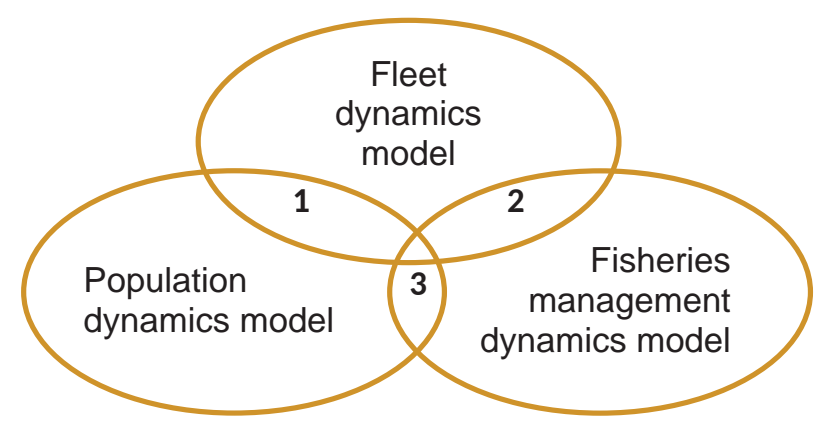





\section{Environmental scenario planning}

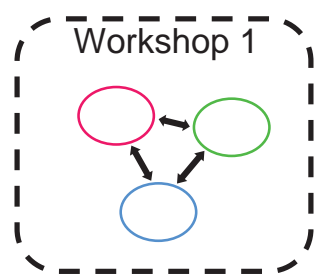

State of the art

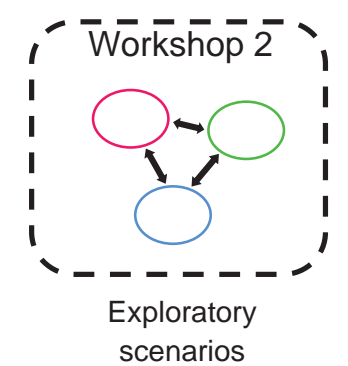

scenarios

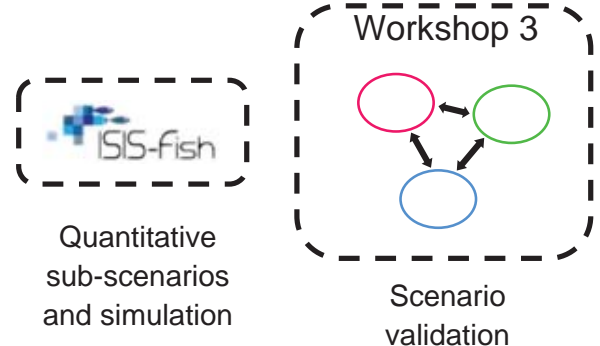

validation 


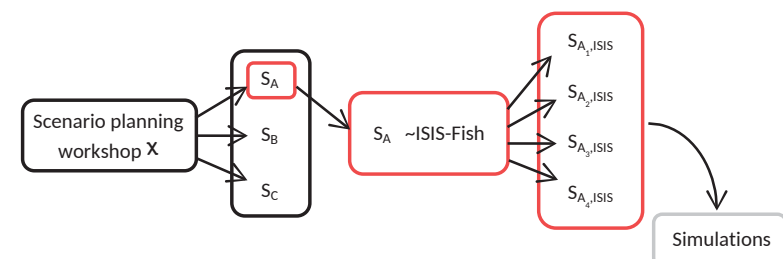

Scenario planning
workshop $\mathrm{X}+1$$\leftarrow \mathrm{S}_{\mathrm{A}} \leftarrow$ Output variables 

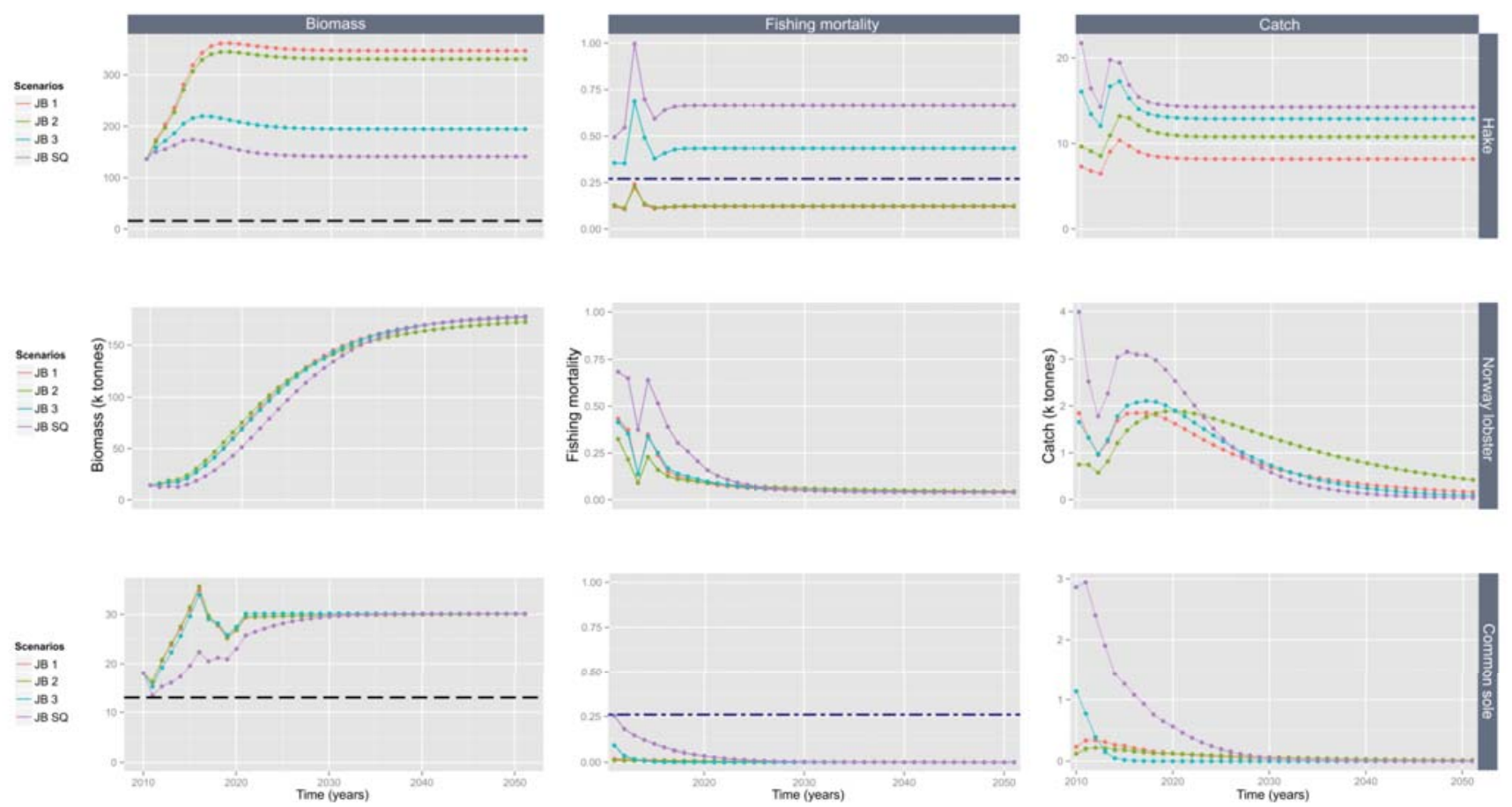
(a)

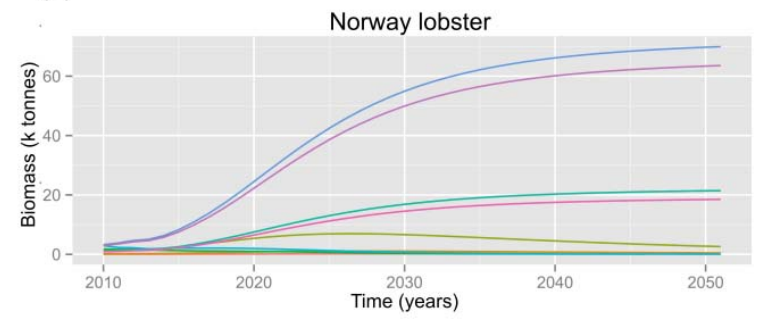

Zones - 20E7 - 21E6 $-21 \mathrm{E} 7-22 \mathrm{E} 6-22 \mathrm{E} 7-23 \mathrm{E} 5-23 \mathrm{E} 6-24 \mathrm{E} 5-24 \mathrm{E} 6$

(b)

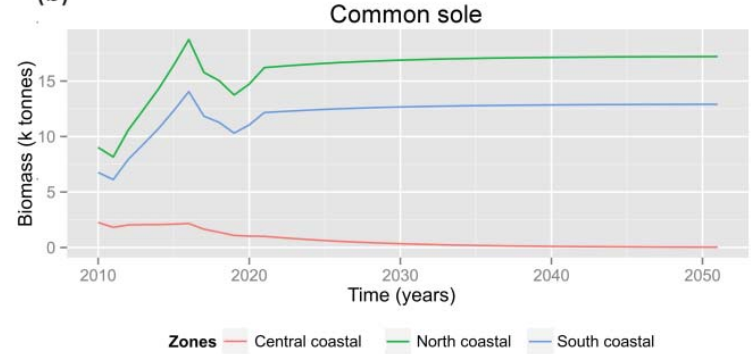

(c)

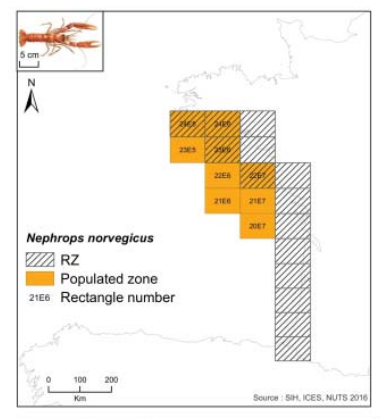

(d)

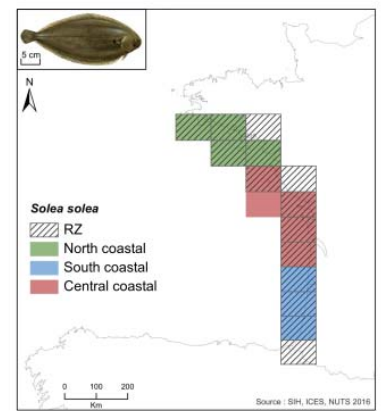




\begin{tabular}{|c|c|c|}
\hline Variable & Description & $\begin{array}{l}\text { Variable that could be modeled in ISIS-Fish (with an example for those } \\
\text { selected for modelling sub-scenarios) }\end{array}$ \\
\hline $\begin{array}{l}\text { Operating } \\
\text { mode of fishery } \\
\text { management }\end{array}$ & $\begin{array}{l}\text { Privatization : access to maritime } \\
\text { spaces and marine resources is } \\
\text { based on financial markets }\end{array}$ & $\begin{array}{l}\checkmark \times \\
\text { Management measures (TAC set by industrial lobbies to reach economic } \\
\text { reference points) }\end{array}$ \\
\hline Fleets & $\begin{array}{l}\text { Standardization : vessels are } \\
\text { harmonized to reduce production } \\
\text { costs }\end{array}$ & $\begin{array}{l}\checkmark \checkmark \\
\text { Types of vessels, Fleets, Strategies (Decommissioning scheme: } \\
\text { withdrawal of fishing vessels from the fleet to keep vessels of the same } \\
\text { length operating the same annual fishing strategy) }\end{array}$ \\
\hline Vessels & $\begin{array}{l}\text { ultra-modern and ultra-selective } \\
\text { vessels to meet the fisheries } \\
\text { sustainability and performance } \\
\text { criteria }\end{array}$ & $\begin{array}{l}\checkmark \times \\
\text { Types of vessels, Fishing métiers } \\
\text { (ban of trawling: change of fishing gears moving from trawl to net or } \\
\text { and line operated by vessels with low gas emission) }\end{array}$ \\
\hline $\begin{array}{l}\text { Multiple } \\
\text { marine uses }\end{array}$ & $\begin{array}{l}\text { Spatial partition of the Bay of } \\
\text { Biscay : patchwork of economic } \\
\text { concessions to maximize the } \\
\text { profitability }\end{array}$ & $\begin{array}{l}\checkmark \checkmark \\
\text { Management measures, Zones, Fishing métiers (Banning fishing } \\
\text { activities from a coastal area in favour of sediment extraction or wind } \\
\text { farm) }\end{array}$ \\
\hline $\begin{array}{l}\text { Controlling } \\
\text { system }\end{array}$ & $\begin{array}{l}\text { Strengthened polluter pays system } \\
\text { through a "sustainable fishing" } \\
\text { charter }\end{array}$ & $\begin{array}{l}\checkmark \times \\
\text { Management measures, Fishing métiers (Reduction of fishing time in } \\
\text { proportion to the environmental impact of fishing métiers) }\end{array}$ \\
\hline
\end{tabular}


Precarious and privatized

$x \times$

monitoring : scientific expertise

Science

subject to lobbying (financial and

political), applied research

dedicated to strategic topics 
Table I. Structural variables of the ISIS-Fish model

Table 2. Variables of the "Jaws in the Bay" scenario, their description, their ability be modeled (yes $=\checkmark$ or no $=\boldsymbol{x}$, first tick) in ISIS-Fish and if the variables selected (yes $=\checkmark$ or no $=\mathbf{x}$, second tick) for simulation of sub-scenarios with ISIS-Fish

Table 3. Sub-Scenarios JB, associated annual fishing effort and number of vessels involved 


\begin{tabular}{ll}
\hline Variable & Characteristics \\
\hline Zones & Spatial distributions of fish populations, fishing métiers and area restrictions \\
\hline Species & $\begin{array}{l}\text { Seasons, life traits (natural mortality rate, average weight, maturity ogive), reproduction, } \\
\text { group (size or weight class), catchability, migration, commercial value (prize) }\end{array}$ \\
\hline Gears & Range (mesh size, net length, etc), selectivity, catchable species \\
\hline Fishing métiers & Season and zones, target species, tightness of targeting \\
\hline Type of trip & Duration, minimum time between two trips \\
\hline Types of vessel & Length, speed, maximum duration of trip, costs \\
\hline Fleets & $\begin{array}{l}\text { Home port, type of vessel, number of vessels, fixed costs, efficiency, fishing métiers and } \\
\text { fishing effort and financial parameters }\end{array}$ \\
\hline Strategies & Fleet, proportion of fleet, inactivity equation, proportion of fishing méteiers per month \\
\hline $\begin{array}{l}\text { Management } \\
\text { measures }\end{array}$ & $\begin{array}{l}\text { Total Allowable Catches, Marine Protected Area, Selectivity restriction, Fishing effort } \\
\text { reduction, associated fishermen reaction, seasons and zones }\end{array}$ \\
\hline
\end{tabular}




\begin{tabular}{ccc}
\hline Sub-scenario & $\begin{array}{c}\text { Fishing effort } \\
\left(\text { hours yr }{ }^{-1}\right)\end{array}$ & Number of vessels \\
\hline $\mathrm{JB}_{\mathrm{I}}$ & 95562 & $20 \mathrm{I}$ \\
\hline $\mathrm{JB}_{2}$ & 227466 & 232 \\
\hline $\mathrm{JB}_{3}$ & 324109 & 502 \\
\hline $\mathrm{JB}$ SQ & 422187 & 703 \\
\hline
\end{tabular}


Annex 2 - Scenario Jaws in the Bay

Scenario: Jaws in the Bay

\section{Assumptions}

I.I - Government policies and participation

After a political or financial crisis, the government loses its authority at sea to private organizations. Access to maritime spaces and marine resources is based on financial markets.

I.2 - Scientific monitoring of marine ecosystems and maritime societies

Private funds are substituted for public research funds in the form of generalized calls for projects. Fisheries science expertise is clearly under the control of economic and political lobbies but the huge diversity of results leads to dispute over accepted "scientific opinion".

Only applied research and strategic topics continue. To counterbalance this, crowd science develops around certain accessible, high profile areas.

\section{I.3 - Cohabitation of uses at sea}

The Bay of Biscay is divided into a patchwork of economic concessions to maximize the profitability of maritime space. Some of these are allocated as reserves. The future of fishing in this partitioned system is uncertain.

I.4 - Maritime fishing management

To ensure food self-sufficiency and the sustainability/performance of maritime management, the government introduces fleet renewal planning schemes. The fleets
COSELMAR

\section{Summary of scenario}

The collapse of the French interventionist model affects all production activities which then function exclusively on private funds. The government also bows out of infrastructure policies. The Public Maritime Domain is then open to concession and compensation markets.

Fishing is carried out mainly in the fishery concessions but agreements with other concessionaires are tolerated.

Transferable quotas are held by large industrial or cooperative shipping companies, non government organizations and businesses. These cede quotas to fishing companies for services rendered (gear maintenance, data collection, etc). 
are standardized to achieve economies of scale.

2 A "sustainable fishing" charter sets out environmental, social and financial criteria. The vessels and fishing companies must meet a certain number of these criteria to be allowed to fish.

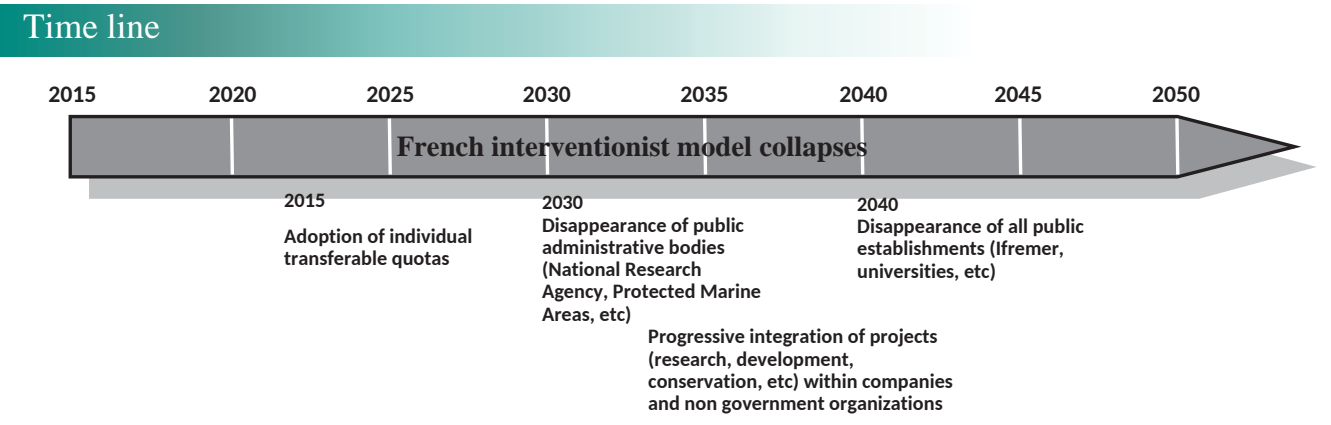

Schematic

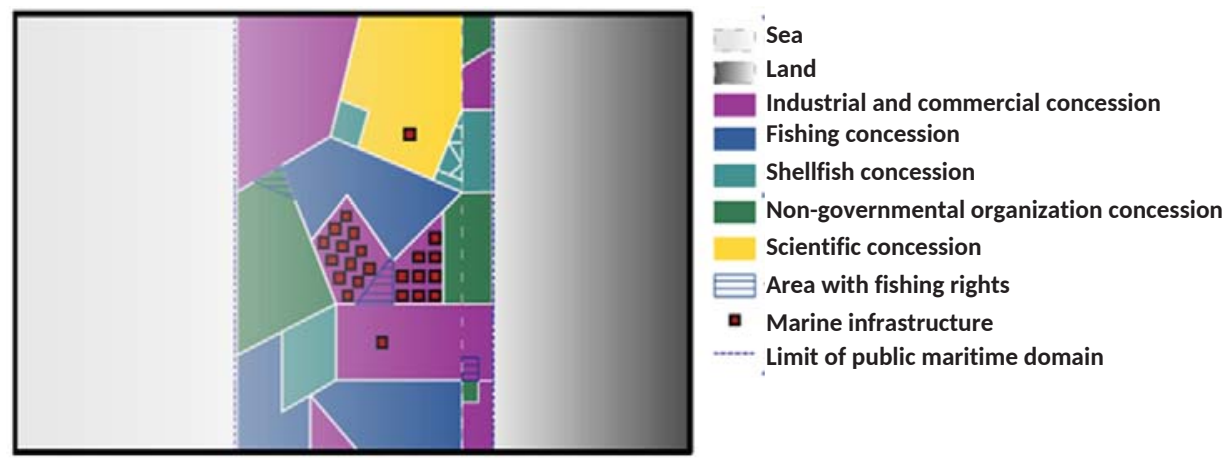

Appendix. Scenario overview for "Jaws in the Bay" produced by Laurie Tissière after the second environmental scenario planning workshop 
Annex parameter_warehouse_GdGNephropsHakeSole2015

\begin{tabular}{|c|c|c|c|c|c|}
\hline Category & Parameter & Value & Origin/Reference & Unit & Description \\
\hline Region & $\begin{array}{l}\text { Min Latitude } \\
\text { Max Latitude } \\
\text { Min Longitude } \\
\text { Max } \\
\text { Longitude }\end{array}$ & $\begin{array}{l}43 \\
48 \\
-8 \\
-1\end{array}$ & & $\begin{array}{l}\text { degree } \\
\text { degree } \\
\text { degree } \\
\text { degree }\end{array}$ & \\
\hline Cell & $\begin{array}{l}\text { Latitude } \\
\text { Longitude }\end{array}$ & $\begin{array}{l}0,5 \\
0,5\end{array}$ & ICES rectangle & $\begin{array}{l}\text { degree } \\
\text { degree }\end{array}$ & \\
\hline $\begin{array}{l}\text { Species } \\
\text { Nephrops }\end{array}$ & $\begin{array}{l}\text { Number of } \\
\text { groups } \\
\text { number of } \\
\text { sexes }\end{array}$ & 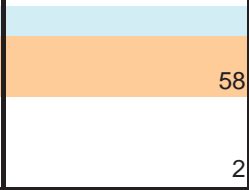 & & $\begin{array}{l}\text { length } \\
(\mathrm{mm}) \\
\text { males } \\
\text { and } \\
\text { females }\end{array}$ & \\
\hline & $\mathrm{K}$ & $\mathrm{f}=-0,11 ; \mathrm{m}=-0,14$ & & & Von Bertalanffy cephalothoracic growth curve \\
\hline & Linf & $f=56 ; m=76$ & & $\mathrm{~mm}$ & \\
\hline & TO & 0 & & months & \\
\hline & $\begin{array}{l}\text { Number of } \\
\text { Zones }\end{array}$ & 9 & & & \\
\hline & Reproduction & January & & & \\
\hline & $\begin{array}{l}\text { Group } \\
\text { Change }\end{array}$ & $\begin{array}{l}\text { January - April - } \\
\text { October }\end{array}$ & & & $\begin{array}{l}\text { Recruitment in group } 0 \text { is allocated to group } 1 \text { for male and female in } \\
\text { January with a } 0.5 \text { ratio. Both males and females change group in April. } \\
\text { Only males and immature females change group in October. Thus males } \\
\text { grow faster than females. }\end{array}$ \\
\hline & $\begin{array}{l}\text { Natural } \\
\text { Mortality }\end{array}$ & $\begin{array}{l}0 \text { for group } 0 ; 0.3 \\
\text { for groups } 1 \text { to } 41 ; \\
0.2 \text { for groups } 42 \text { to } \\
58\end{array}$ & ICES (2014) & & \\
\hline
\end{tabular}




\begin{tabular}{|c|c|c|c|c|c|}
\hline & Weight-at-age & $\begin{array}{l}(\text { length })^{\wedge} 3.18^{\star} 0.39 / 1 \mathrm{e} \\
6 \text { if group }<34 \\
\text { (length) }{ }^{\wedge} 2.97^{\star} 0.81 / 1 \mathrm{e} \\
6 \text { if group }>=34\end{array}$ & $\begin{array}{l}\text { ICES (2014) } \\
\text { Table10.4 : } \\
\text { Conan } 78 \text { \& } \\
\text { Verdoit et al } 99\end{array}$ & $\mathrm{~kg}$ & \\
\hline & $\begin{array}{l}\text { Length-at- } \\
\text { maturity }\end{array}$ & $\begin{array}{l}26 \mathrm{~mm} \text { for both } \mathrm{m} \text { and } \\
\mathrm{f}\end{array}$ & ICES (2014) & $\mathrm{mm} \mathrm{CL}$ & $\begin{array}{l}\text { The choice of a } 26 \mathrm{~mm} \text { length at maturity is a compromise that seems } \\
\text { acceptable when looking at ICES WGBIE values. } 2 \text { different sources of } \\
\text { information in the report. "appendix" section: } L \text { mat }=20 \mathrm{~mm} \text { CL }(6.5 \mathrm{~cm}) \text { for } \\
\text { males and } 24 \mathrm{~mm} \text { CL (8cm) for females; "input parameters" section: } L \mathrm{mat}= \\
26,3 \mathrm{~mm} \text { CL for males (WKNEPH2006) and } 25 \mathrm{~mm} C L \text { for females (Morizur } \\
\text { 1982) }\end{array}$ \\
\hline & Recruitment & 67660000 & $\begin{array}{l}2001-2010 \text { average } \\
\text { recruitement; ICES } \\
\text { (2014) }\end{array}$ & $\begin{array}{l}\text { inds per } \\
\text { zone }\end{array}$ & \\
\hline & Catchability & & & & $\begin{array}{l}\text { Catchability is identical all year long for juveniles of males and females } \\
\text { (juveniles correspond to the } 9 \text { first groups). } Q=0 \text { for group } 0(<10 \mathrm{~mm}) \text {. } Q=0 \\
\text { from September to March ( } 7 \text { months corresponding to the incubation of } \\
\text { eggs). }\end{array}$ \\
\hline & Migrations & NO & & & \\
\hline & Price & $\begin{array}{l}8.3 \text { if } w<25 g ; 9.07 \text { if } \\
25 g<w<33 g ; 9.82 \text { if } \\
33 g<w<50 g ; \\
13.41 w>50 g\end{array}$ & Gourguet (2013) & $\begin{array}{l}\text { euros / } \\
\mathrm{kg}\end{array}$ & Average price per commercial category for year 2010 \\
\hline Hake & $\begin{array}{l}\text { Number of } \\
\text { groups }\end{array}$ & 65 & & $\begin{array}{l}\text { Length } \\
(\mathrm{cm}) \\
\end{array}$ & \\
\hline & $\begin{array}{l}\text { number of } \\
\text { sexes }\end{array}$ & & & & \\
\hline & $\mathrm{K}$ & 0,177319 & & & VB growth curve \\
\hline & Linf & 130 & & $\mathrm{~cm}$ & \\
\hline & 10 & 0 & & months & \\
\hline & $\begin{array}{l}\text { Number of } \\
\text { Zones }\end{array}$ & 4 & & & \\
\hline & Reproduction & January & & & \\
\hline
\end{tabular}




\begin{tabular}{|c|c|c|c|c|c|}
\hline & $\begin{array}{l}\text { Group } \\
\text { Change }\end{array}$ & January - April - July & & & \\
\hline & $\begin{array}{l}\text { Natural } \\
\text { Mortality }\end{array}$ & 0.4 & $\begin{array}{l}\text { ICES (2014), } \\
\text { Annex B, } \\
\text { Section7.2 }\end{array}$ & & \\
\hline & Weight-at-age & $\begin{array}{l}\text { (length)^3.074*5.1 } \\
3 / 1 \mathrm{e} 6\end{array}$ & $\begin{array}{l}\text { Annex B.2 p } 482 \\
\text { of ICES (2014) }\end{array}$ & $\mathrm{kg}$ & \\
\hline & $\begin{array}{l}\text { Length-at- } \\
\text { maturity }\end{array}$ & $\begin{array}{l}(1 /(1+\exp (- \\
0.2^{*}(\text { length- } \\
42.85))))\end{array}$ & & $\mathrm{cm}$ & ( $50 \%$ of fish are mature when reaching $42.85 \mathrm{~cm}$ ) \\
\hline & Recruitment & 103704859 & $\begin{array}{l}\text { ICES (2014), } \\
\text { Annex B, } \\
\text { Section7.2 }\end{array}$ & $\begin{array}{l}\text { individua } \\
\text { Is }\end{array}$ & $\begin{array}{l}\text { Average } 2001-2010 \text { recruitment on the whole assessment area }=300785.6 \\
* 10^{\wedge} 3.34 .478 \% \text { of the catch from this area comes from the Bay of Biscay, } \\
\text { this ratio is applied to the whole recruitment to obtain the BoB recruitment }= \\
300785.6 * 10^{\wedge} 3 * 0.34478=103704859 \text { individus }\end{array}$ \\
\hline & Catchability & & & & $\begin{array}{l}\text { Catchability is identical for all seasons. Catchability for groups below } 30 \text { is } \\
\text { lower than that of groups above or equal } 30 \text {. }\end{array}$ \\
\hline & Migrations & January, April, July & & & $\begin{array}{l}\text { In January mature fish move from all areas to the reproduction area, in } \\
\text { April } 60 \% \text { of the mature fish move from the reproduction area to the coastal } \\
\text { presence area, in July mature fish from the coastal area and the } \\
\text { reproduction area move to the more offshore presence zone. }\end{array}$ \\
\hline & Price & $\begin{array}{l}3.69 * 0.54 \text { if } \\
\operatorname{length}<10 \mathrm{~cm} \text {; if } \\
(\lg >=10.0 \& \& \\
\lg <18.5) 3.69 * 0.79 \\
\text { if }(\lg >=18.5 \& \& \\
\lg <26.0) 3.69 * 1.11 ; \\
\text { if }(\lg >=26.0 \& \& \\
\lg <32.5) 3.69 * 1.49\end{array}$ & Gourguet (2013) & & $\begin{array}{l}\text { The link between the price at age at the price at length is made using the } \\
\text { von Bertalanffy growth curve for Hake }\end{array}$ \\
\hline Sole & $\begin{array}{l}\text { Number of } \\
\text { groups }\end{array}$ & 7 & & $\begin{array}{l}\text { Age } \\
\text { (Years) }\end{array}$ & from age 2 to age 8 \\
\hline & $\begin{array}{l}\text { number of } \\
\text { sexes }\end{array}$ & t & & & \\
\hline
\end{tabular}




\begin{tabular}{|c|c|}
\hline K,Linf,TO & $\begin{array}{l}\text { Growth in months, should affect selectivity if the sole selectivity equation } \\
\text { were known. Here, as sole selectivity is } 1 \text { for all gears that fish sole and } \\
\text { only the Target Factors are known this will not change anything. }\end{array}$ \\
\hline $\begin{array}{l}\text { Number of } \\
\text { Zones }\end{array}$ & \\
\hline Reproduction & $\begin{array}{l}\text { If (group.getld }()==0 \text { ) return 0.32; else if (group.getld }()==1 \text { ) return 0.83; } \\
\text { else if }(\text { group.getld }()==2 \text { ) return 0.97; else if (group.getld }()>=3 \text { ) return } \\
1.0 ;\end{array}$ \\
\hline \begin{tabular}{|l|} 
Group \\
Change
\end{tabular} & January \\
\hline $\begin{array}{l}\text { Natural } \\
\text { Mortality }\end{array}$ & 0,1 \\
\hline Weight-at-age & $\begin{array}{l}\text { Weight at age in catches } 2010 \text { from WGBIE 2014, corrected to get } \\
\text { the weight at age in stock if (group == null) return 0.0; else if } \\
\text { (group.getId() == 0) return 0.191; else if (group.getId() == 1) return } \\
0.220 \text {; else if (group.getId()==2) return 0.290; else if (group.getId() } \\
==3 \text { ) return } 0.360 \text {; else if (group.getId() == 4) return 0.442; else if } \\
\text { (group.getId() == 5) return 0.509; else if (group.getId()==6) return } \\
0.820 ; \quad \text { else return 0; }\end{array}$ \\
\hline Recruitment & $\begin{array}{l}\text { Equation Hockey-Stick : recrutement = pente*ssb si ssb < ssblim, } \\
\text { recr(ssblim), Parametres pour stock en kg et recrutement en nombre; } \\
\text { double pente = 1.77; double ssbmin = 9.67*Math.pow }(10,6) \text {; double } \\
\text { rssbmin = } 1.71 * \text { Math.pow }(10,7) ; \text { if }(\text { ssb }<\text { ssbmin }) \text { \{recrudszone = } \\
\text { pente*ssb; }\} \text { else } \text { \{recrudszone = rssbmin; }\end{array}$ \\
\hline Catchability & 5.66E-7;1.89E-6;3.82E-6;2.37E-6;1.47E-6;1.31E-6;1.31E-6; \\
\hline Price & Prices from Gourguet, 2013 \\
\hline
\end{tabular}

|Bibliography

Gourguet, S. (2013) cological and economic viability for the sustainable management of mixed fisheries . PhD Thesis , University of Tasmania, Université de 
Bretagne Occidentale . http://archimer.ifremer.fr/doc/00206/31731/;

ICES (2014).

Report of the Working Group for the Bay of biscay and the Iberian waters Ecoregion (WGBIE), 7-13 may 2014, lisbon, portugal. ICES CM 2014/ACOM :11. 714

pp.; Conan, G. (1978). Average growth curves

and history in a Nephrops norvegicus population from Northern Bay of Biscay. ICES CM

Verdoit M., Pelletier D., Talidec C., 1999, A growth model that incorporates individual variability for the Norway lobster population (Nephrops norvegicus L., 1758) of the Bay of Biscay. ICES J.Mar. Sci. 56, 734-745. 